DOI 10.18551/rjoas.2021-09.03

\title{
HANDLING THE ECONOMIC IMPACT OF THE COVID-19 PANDEMIC ON TOURISM VILLAGE AREA
}

\author{
Putra I Wayan Gde Yogiswara Darma*, Indriyani Ni Made Vita \\ Faculty of Economics and Business, Warmadewa University, Indonesia \\ *E-mail: yogiswaradarmaputra@gmail.com
}

\begin{abstract}
The COVID-19 pandemic has had a significant impact on the life of the world community, including in Indonesia. In addition to the health impact, the pandemic also has an economic impact, thus prompting the government to make various policies to overcome these impacts. Policies by optimizing state and regional budgets for the needs of preventing the spread and handling of the health impacts of COVID-19 and optimizing local economic potential meet community needs in a sustainable manner. The potential that can be increased in supporting the village's original income is in the tourism sector. In the concept of a tourist village, the active role of the development and management of a tourist village is in the hands of the village community. In this case, the village community does not become an audience but becomes an active player in managing tourist attractions in their village so that they can finally get economic benefits in the form of increasing Regional Original Income. The purpose of this study is to understand, describe and analyze how the strategy for handling the economic impact of the COVID-19 pandemic is the Taro Village Government. The data analysis techniques used are interviews, literature study and documentation. The data obtained will be analyzed using qualitative descriptive analysis techniques. The results of this study are expected to provide a reference for the Taro Village community regarding the strategy for handling the economic impact of the COVID-19 pandemic, the Taro Village Government.
\end{abstract}

\section{KEY WORDS}

COVID-19, economic impact, tourism, village.

The COVID-19 pandemic has an economic impact on the collapse of the business world, poverty and even hunger. Socially, it has the potential to cause considerable conflict turmoil, religious and worship conflicts, disharmony conflicts due to poverty, to confrontational conflicts due to inappropriate government policies. COVID-19 has significantly impacted the economy in various sectors, namely the household sector, MSMEs, corporations and the financial sector, both private and state. Besides threatening the health of thousands, tens of thousands, maybe even hundreds of thousands of citizens. Also millions and even tens or hundreds of millions of people (still difficult to predict) are threatened with losing their income and ability to meet their minimum needs, resulting in a decline in people's purchasing power. Furthermore, if it cannot be handled properly, it will not only impact poverty but also the impact of hunger on certain communities. The corona virus pandemic has had an impact on the declining purchasing power of the poor, both in rural and urban areas. Informal workers who depend on their daily income have been hit hard by the policy of social-physical distancing and work from home as a way to prevent the spread of the corona virus. With the scale and speed of its spread, this pandemic will have a severe impact on all aspects of life.

COVID-19 causes impacts such as in the field of work where many layoffs are carried out, changes in people's behavior, especially in the health sector, to the economic impact. Potential problems that arise due to COVID-19 and must be considered by the Regional Government, include: Limited budget availability for handling COVID-19 in the 2020 FY APBD; The unavailability of health facilities and infrastructure for handling COVID-19; Unpreparedness of medical personnel in dealing with COVID-19; Lack of medical personnel in handling COVID-19; Availability of food and basic needs disrupted due to panic buying; 
Daily workers of lower-level economic actors (restaurant waiters, motorcycle taxis, street vendors, etc.) cannot work so they have no income; There is the possibility of layoffs for closed industries; and The potential for APBD revenues from the Regional Original Revenues (especially taxes and levies) is not optimal and the APBD absorption is not optimal due to the impact of the Work from Home policy. The government carries out preventive measures, including optimizing available resources, including financing, facilities, and infrastructure using the APBD, especially the 2020 health DAK and the Village Fund for handling the COVID-19 outbreak and optimizing local potential/Optimizing local potential which can be an alternative fulfillment community needs, especially to meet the basic needs of the community.

In order to maintain economic and social stability in Indonesia, the government is also promoting the Social Safety Net program, including by providing electricity subsidies for underprivileged families, pre-employment cards for workers affected by layoffs, basic food cards, Family Hope Program, Cash Social Assistance, Social Assistance for Basic Foods, Direct Cash Assistance, village funds, and others. Local governments are also encouraged to provide social safety nets through the provision of grants/social assistance in the form of money and/or goods, this social safety net will be provided to individuals/communities affected by COVID-19 or have social risks (such as poor families and informal workers), public/private health facilities that participate in handling COVID-19 and vertical agencies that participate in supporting the handling of COVID-19 (Tjenreng, 2020).

In general, the efforts made by the government in preventing economic impacts that threaten the welfare of the community are carried out as a whole, because if the technical impact of preventing the spread of COVID-19 has not been carried out optimally, then the economic impact cannot be overcome to the maximum, then the government implements preventive measures. among others, (1) Consistently implement instructions for handling COVID-19, all instructions from the government and local governments related to handling COVID-19 such as PSBB and the use of masks; (2) Optimizing available resources, including financing, facilities, and infrastructure using the APBD, especially the 2020 health DAK and the Village Fund for the prevention of the COVID-19 outbreak; (3) Optimizing local potential, Optimizing local potential can be an alternative to meet community needs, especially to fulfill the basic needs of the community; (4) Development of financial inclusion, by increasing public access to formal financial services, especially low-income communities; (5) Improving the implementation of intervention efforts. Through policies such as credit relaxation and capital assistance, it is hoped that it will run effectively for the community; and (6) Increased collaboration of all relevant sectors. Collaboration between the government, private sector, NGOs, universities and the community is needed both for information transfer and policy implementation (Tjenreng, 2020).

Based on the various rules that have been applied above, local governments implement them according to the situation and conditions that exist in their area. The same is true in Bali, as one of the provinces prone to the spread of COVID-19. The cause of this vulnerability is because Balinese people have a high level of mobility as a result of world tourist destinations. In addition, Bali has become one of the urbanization centers of various regions in Indonesia. Therefore, it is important to immediately implement the policies of the central government. The form of implementation in the Province of Bali is by forming a mutual cooperation task force involving the traditional village component which was originally named Pakraman Village. It is the efforts and policies of the government that are expected by all Indonesian people. One of the efforts that the government is currently doing is to provide various kinds of social assistance in the hope that the community's needs will still be met even though there are restrictions that make people unable to carry out their daily activities as usual. (Livana, 2020)

The COVID-19 outbreak that has hit Bali since March 2020 has paralyzed activities in all sectors. This pandemic is uncertain when it will end, making the tourism sector hit hard. Tourist visits to Bali are almost zero percent. Various types of businesses that rely on this sector can barely move because there is no income from tourism objects. The tourism village development program not only aims to encourage rural communities to creatively manage 
their natural and cultural potential so as to produce economic benefits, but more than that, it also aims to prepare the community to face global competition. In other words, the development of tourist villages has the main goal of building rural communities to have cultural and economic resilience. With economic support or adequate capital, rural communities will be able to maintain and develop their cultural heritage. Thus, in developing a tourism village with a 'pro-people' character, the goal and target is to provide opportunities or encourage the community to be more active, creative, and pro-active in developing and managing tourist attractions in their area. Taro Village, Tegallalang District, Gianyar Regency, is considered to have succeeded in overcoming problems during the COVID-19 outbreak. So that it was chosen to be the village that represents the COVID-19 Free Productive Village 2020. In fact, it has now become a place for comparative studies by other districts in Bali.

Tourism Village is a community or community consisting of residents of a limited area who can interact directly with each other under a management and have the care and awareness to play a role together according to their respective skills and abilities, empowering potential conducive to the growth and development of tourism and the realization of Sapta. Enchantment so as to achieve increased regional development through tourism and use it for the welfare of the people in the region. Handling the economic impact of the COVID-19 pandemic on Tourism Villages, which has been intensively carried out, has forced tourism village managers to prepare unique ideas. One of them was carried out by the Nglanggeran Tourism Village, which prepared a digital tour package, entitled Virtual Tour of Nglanggeran Tourism Village. The Nglanggeran Tourism Village Virtual Tour Program is in the form of tourist activities or walks that are carried out online or online. This can also be taken into consideration by tourist villages such as Taro to carry out a good strategy in handling the economic impact during the COVID-19 pandemic. In addition to strategies and innovations that must be carried out by tourist villages, government support is also very necessary in handling the economic impact during the pandemic.

\section{METHODS OF RESEARCH}

The problems that will be studied by researchers are social and dynamic problems. Therefore, the researcher chose to use qualitative research methods to determine how to find, collect, process, and analyze the research data. In this study used a qualitative method with a descriptive design, namely research that provides a careful description of certain individuals or groups about the circumstances and symptoms that occur. Furthermore, the researcher will provide a careful description of the phenomena that occur regarding how the strategy for handling the economic impact of the COVID-19 pandemic is the Taro Village Government in the Tourism Village area. In this study, researchers used data collection techniques by means of documentation, literature study and interviews. In qualitative research, data is obtained from various sources, using various data collection techniques (triangulation), and is carried out continuously until the data is saturated. Qualitative data analysis is inductive in nature, namely an analysis based on the data obtained, then a certain relationship pattern is developed or becomes a hypothesis. Data analysis in this study was carried out through three activities that occurred simultaneously, namely data reduction, data presentation, and drawing conclusions or verification

\section{RESULTS AND DISCUSSION}

Local governments have an important role to play in reducing the spread and anticipating the impact of COVID-19, so that local governments are encouraged to continue to monitor their regions with several steps, namely: Prevention of spread, Coordination with Forkopimda, community organizations and community leaders to reduce the spread of COVID-19. In optimizing activities, local governments are encouraged to increase the capacity for handling health, economic impacts and social security. Ensuring community needs, Ensuring the adequacy of basic necessities and the sustainability of the industry in 
the region. The application of regional innovation, the application of regional innovation to maintain economic stability in the region. Taro village has a beautiful natural charm. The history of Taro Village cannot be separated from the existence of the white ox which is considered a sacred animal. This village is a small village located in the northern part of Ubud, precisely in Tegalilalang District, Gianyar Regency. Taro was once just a traditional Balinese village with a deep historical heritage. But today, this place has completely transformed into a modern attraction for tourists who crave the beauty of the tropical countryside, although it still maintains its spiritual image. Taro Village in the COVID-19 pandemic season is still active and active in food security with a creative economy. Especially through tourism innovation through the Taro Tourism Village called Eco-Spiritual Destination.

The development of tourist villages depends on BUMDES. This includes eco-spiritual which is one of Taro Village's strategies to attract tourists. Later this strategy is expected to improve the village economy. Eco-spiritual itself has its origins in the 7th century, where Taro Village is an old village that has been processing an integrated farming system in the form of subak. In addition, Taro Village which has the heritage of Gunung Raung Temple, Lembu Putih and several other temples in the form of a phallus. So that spiritually tourism villages have existed for a long time, but are now being redeveloped to improve the village economy. The concept of tri hita karana is used in the application of eco-spiritual such as yoga which can provide a sense of comfort to tourists. Especially during a pandemic like now, physical and mental health is very necessary. Taro Village's vast land and fresh air are also factors that are safe and comfortable for tourists, so that the COVID-19 pandemic process can be carried out. Eco-spiritual itself is not only related to spiritual tourism, but the existence of a sustainable natural relationship in accordance with the concept of tri hita karana. The community will be involved in the development of eco-spiritual. This is because Taro Village will cooperate with the community for the development of home stays and local culinary that will help the village in attracting tourists to come to Taro Village. From this collaborative process, the profits will be managed by the village to be distributed to the community and used for village development. BUMDES will play a role in distribution to the community. In addition to the eco-spiritual strategy, Taro Village is also developing firefly conservation as a night tour that can be enjoyed by tourists. Taro Village provides tour packages from airport pick-up to accommodation and transportation. The village strategy to attract tourists is also by using the web and brochures. In addition, STT Taro Village also helps the development of tourist villages by making interesting videos to share on social media.

\section{CONCLUSION}

Handling the economic impact of the COVID-19 pandemic on the tourist village area in Taro Village can be said to be successful because the village has introduced eco-spiritual which is one of Taro Village's strategies to attract tourists. Later this strategy is expected to improve the village economy. The concept of tri hita karana is used in the application of ecospiritual such as yoga which can provide a sense of comfort to tourists. Especially during a pandemic like now, physical and mental health is very necessary. Taro Village's vast land and fresh air are also factors that are safe and comfortable for tourists, so that the COVID-19 pandemic process can be carried out. Eco-spiritual itself is not only related to spiritual tourism, but the existence of a sustainable natural relationship in accordance with the concept of tri hita karana. In handling COVID-19, the Taro Village Government directly supervised the health program carried out in each official village. In addition to providing funds that have been budgeted for the anticipation of COVID-19, the Village Government also conducts outreach activities at any time, spraying disinfectants, which later aim is to protect village communities from being affected by this virus. In addition to the Village Government, each official village also participates in budgeting and preparing equipment to anticipate this virus, including each official village has been provided with hand washing equipment, disinfectant to be sprayed on residents' homes, masks for residents, and hand sanitizer. This cohesiveness between the Village Government and the Village Service has 
strengthened the handling of COVID-19 in Taro Village so that there are almost no COVID19 cases in Taro Village.

\section{REFERENCES}

1. Efendi, L., Lutthfatul, A. L., Alfiatuzulfa, Fidra, D. and Aisa, S. (2020). Analysis of the Impact of the COVID-19 Pandemic on the Tourism Sector of the Nongkosawit Village. Research Article Joint Real Work Lecture Against COVID-19 Semarang State University 2020.

2. Livana, et al (2020). The Impact of the COVID-19 Pandemic for the Village Community Economy. Indonesian Journal of Nursing and Health Sciences

3. Tjenreng, M. Zamzami B. (2020). Government and Local Government Policies in Handling COVID-19 and Its Effects on the National Economy", presented at the webinar: ARS University. Yogyakarta.

4. Ulya, Husna. 2020. Alternative Strategies for Handling the Economic Impact of COVID-19 East Java Regional Government in Agropolitan Areas. Journal of Islamic Economics and Business

5. World Health Organization. (2020). Coronavirus disease 2019 (COVID-19). https://COVID19.who.int/ 